\title{
Capital Structure and Corporate Governance Mechanisms in Kuwait Stock Exchange (KSE)
}

\author{
Mejbel Al-Saidi ${ }^{1}$ \\ ${ }^{1}$ College of Business Studies, PAAET, Kuwait \\ Correspondence: Mejbel Al-Saidi, College of Business Studies, Kuwait. E-mail: Al-SaidiMTMT@hotmail.com
}

Received: March 25, 2020

Accepted: April 16, 2020

Online Published: May 10, 2020

doi:10.5539/ijef.v12n6p38

URL: https://doi.org/10.5539/ijef.v12n6p38

\begin{abstract}
The study investigated the impact of corporate governance mechanisms on the corporate capital structure of the Kuwait Stock Exchange (KSE). Specifically, this study linked five corporate governance mechanisms-large shareholder ownership concentration, government ownership concentration, board size, board independence, and family directors-with capital structure for 81 non-financial listed firms between 2017 and 2018. The data indicated that only government ownership concentration and family directors affect capital structure.
\end{abstract}

Keywords: capital structure, corporate governance, Kuwait stock exchange, Kuwait

\section{Introduction}

In light of global financial challenges, many studies have suggested that countries use corporate governance mechanisms to solve the related-problems or at least reduce their impact on listed firms. The Cadbury Report (1992, p. 15) defined corporate governance as "the system by which companies are directed and controlled." Several corporate governance mechanisms (e.g., board of directors, ownership structure, financial policies, regulations) have been used in these studies. To minimize the problem of these worldwide financial crises, some studies have examined the relationship between corporate governance and performance or value; others have examined the relationship between disclosure and corporate governance or looked for the optimal corporate governance system to protect countries from financial crises. Yet few studies have examined the relationship between capital structure and corporate governance.

Agency theory argues that a conflict exists between managers (agents) and principals (shareholders) within firms and such conflict may impact the firms' value (Jensen \& Meckling, 1976). La Porta, Lopez-de-Silanes, and Shleifer (1999) found that another conflict exists between large shareholders and small shareholders and between large shareholders and debtholders (creditors). According to agency theory, increasing the debt in capital structure would reduce agency conflicts among shareholders and debtholders because managers will increase their performance to protect their firms from bankruptcy, thereby saving their jobs and reputation. They will work hard to repay the debt and avoid financial crisis. Thus, capital structure can be used to protect shareholders and increase firm performance and value.

Corporate governance rules were enacted in Kuwait in 2012. The New Companies Law and Capital Market Authority declared that all listed firms must apply these rules starting in June 2016. These rules relate to board effectiveness, separation of the CEO and chairman positions, appointment of the chairman and directors, independent directors, director's responsibility, board committees, disclosure, minority shareholders, and the role of large shareholders. Thus, it would be useful to test the corporate governance mechanisms to understand their impact on capital structure and determine which mechanisms work effectively. To the best of the researcher knowledge, no study has examined these relationships in Kuwait. This study used five corporate governance mechanisms: large shareholders' ownership concentration, government ownership concentration, board size, board independence, and family directors. The remainder of this study is organized as follows. Section two presents the literature review and hypothesis development, while section three presents the research design and section four introduces the study results and discussion. Finally, section five concludes this study (Note 1).

\section{Literature Review and Hypothesis Development}

Modigliani and Miller (1958) first considered the importance of capital structure, which means the mix of debt and equity that firms use. Agency theory is an important theory that used capital structure as a mechanism for reducing 
the conflicts of interest stemming from the separation between ownership and control. Jensen and Meckling (1976) argued that the conflicts of interests that arise from the separation of ownership and control lead to agency problems. Thus, firms need more controlling and monitoring to reduce these conflicts inside and outside the firms. La Porta et al. (1999) concluded that agency conflict in some countries could occur among shareholders or between shareholders and debtholders. Jensen (1986) found that debt can reduce the free cash flow available to managers, ensuring that they do not use it in unnecessary and risky projects; thus more debt (or less equity) improves the firm's performance. This literature leads to the following hypotheses:

H1: Ownership concentration negatively impacts capital structure.

H2: Ownership concentration by government negatively impacts capital structure.

H2: Board size negatively impacts capital structure.

H3: Board independence positively impacts capital structure.

H5: Family directors positively impact capital structure.

Empirical studies have produced mixed results (see Table 1). Hypothesis 1 assumes a negative relationship between ownership concentration and capital structure, consistent with agency theory (Jensen \& Meckling, 1976; La Porta et al., 1999) and studies by Boateng, Cai, Borgia, and Ngwu (2017), Heng and Azrbaijani (2012), and Uwuigbe (2014). Hypothesis 2 predicts that government ownership concentration affects capital structure in the same way. Quang and Xin (2015) and Heng and Azrbaijani (2012) found that government ownership concentration positively affects capital structure, but Hafez (2017) found no impact on capital structure. Hussainey and Aljifri (2012) found that the UAE government does not impact capital structure because of limited corporate governance standards.

According to Hypothesis 3, a negative relationship exists between board size and capital structure, consistent with Yermack (1996). However, Hussainey and Aljifri (2012) found no relationship between board size and capital structure in the UAE. In Kuwait, small board size is expected to be more effective and consistent with agency theory as it encourages firms to use more debt. Indeed, Hasan (2009), Uwuigbe (2014), Abobakr and Elgiziry (2016), Heng and Azrbaijani (2012), and Brenni (2014) found that board size negatively affects capital structure.

Table 1. Studies that examined the impact on capital structure

\begin{tabular}{lll}
\hline Authors & Country \& sample & Impact on capital structure \\
\hline Boroujeni et al. (2003) & Iran, 87 firms, 2001-2009 & Ownership concentration (+) \\
Quang and Xin (2015) & Vietnam, 300 firms, 2006-2012 & Government ownership (+), board size, and independent director (none) \\
Chitiavi et al. (2013) & Kenya, 50 firms, 2007-2011 & Ownership concentration, board size, board independence (+) \\
Ahmad et al. (2018) & Pakistan, 56 firms, 2011-2014 & Ownership concentration, board size, and board independence (+) \\
Jaradat (2015) & Jordan, 126 firms, 2009-2013 & Board size (+), independence (none) \\
Agyei and Owusu (2014) & Ghana, 8 firms, 2007-2011 & Ownership concentration, board independence (none), board size (+) \\
Butt and Hasan (2009) & Pakistan, 58 firms, 2002-2005 & Ownership concentration (+), board size (-), independence (none) \\
Boateng et al. (2017) & China, 2386, 1998-2012 & Ownership concentration (-), board independence (+) \\
Hafez (2017) & Egypt, 50 firms, 2007-2016 & Ownership concentration, government ownership, and board size (none) \\
Kajananthan (2012) & Sri Lanka, 28 firms, 2009-2011 & Board size, independence (none) \\
Uwuibe (2014) & Nigeria, 40 firms, 2006-2011 & Ownership concentration, board size, and board independence (-) \\
Hussainey and Ajifri (2012) & UAE, 71 firms, 2006 & Government ownership and board size (none) \\
Brenni (2014) & UK, 26 firms, 2000-2009 & Board size (-) and board independence (+) \\
Hakim and Affes (2015) & Tunisia, 13 firms, 2003-2009 & Ownership concentration and board size (none), board independence (+) \\
$\begin{array}{l}\text { Masnoon and Rauf (2013) } \\
\text { Siromi and Cbandrapala }\end{array}$ & Pakistan, 30 firms, 2009-2011 & Ownership concentration (-), board size (+), board independence (-) \\
$\begin{array}{ll}\text { (2017) } \\
\text { Heng and Azrbaijani (2012) }\end{array}$ & Egypt, 36 firms, 2007-2011 & Ownership concentration (-), government ownership (+), board size (-), \\
& & board independence (none) \\
Abobakr and Elgiziry (2016) & Malaysia, 75 firms, 2005-2008 & Board size (-), board independence (none) \\
\hline
\end{tabular}

Hypothesis 4 predicts board independence's positive impact on capital structure. According to agency theory, board independence effectively reduces conflicts of interest for listed firms. Siromi and Cbandrapala (2017) found a significant positive relationship between board independence and firm debt ratio because board independence reduces agency conflicts within firms. Chitiavi, Musiega, and Alala (2013), Ahmad, Akhter, Siddiq, and Iqbal 
(2018), Boateng, Cai, Borgia, and Ngwu (2017), Brenni (2014), and Hakim and Affes (2015) found similar results. However, Heng and Azrbaijani (2012) and Abobakr and Elgiziry (2016) found no significant relationship between board independence and capital structure in Malaysia or Egypt. Finally, this study argues that family directors positively impact capital structure as, in agency theory, family directors improve firms' performance; in such firms, managers and shareholders are the same person, thereby reducing agency problems inside the firms (Jensen \& Meckling, 1976).

\section{Research Design}

This study examined corporate governance mechanisms' impact on capital structure using data from 81 non-financial listed firms from 2017 to 2018. Financial firms are excluded because of their different structures and regulations. The two years were chosen because these were the most up-to-date data available as the majority of non-financial listed firms had not published their 2019 data at the time of writing; in addition, the Kuwait government introduced new rules for listed firms starting in 2017, so including any data from before 2017 would be irrelevant (Note 2). All information related to the study's variables is publicly available on the Kuwait Stock Exchange (KSE) website except ownership structure, which was collected from newspapers and the KSE website at the end of each year. This study used the debt-to-equity ratio as a dependent variable to measure capital structure and five corporate governance mechanisms as independent variables as well as three control variables. OLS regression was used because it is consistent with the majority of previous studies reviewed, is common, and is easy to understand. OLS regression has five assumptions that must be tested to ensure that our analysis is not misleading or biased. Haniffa and Hudaib (2006) argued that since OLS regression is used to test the hypotheses, the assumptions of multicollinearity, normality, linearity, homoscedasticity, and autocorrelation (independence of the errors) must be tested This study used the following equation to examine the impact of corporate governance mechanisms on capital structure, and all variables are explained in Table 2.

$$
C S=\alpha_{0}+\beta_{1} O C+\beta_{2} G O C+\beta_{3} B S+\beta_{4} B I+\beta_{5} F D+\beta_{6} F S+\beta_{7} F A+\beta_{8} I N D+\varepsilon
$$

Table 2. Study variables

\begin{tabular}{ll}
\hline Variables & Definitions \\
\hline $\begin{array}{l}\text { Dependent variables } \\
\text { Capital structure (CS) }\end{array}$ & Debt-to-equity ratio \\
\hline & \multicolumn{1}{c}{ Independent variables } \\
\hline Ownership concentration (OC) & Shareholdings held by major shareholders (more than 5\%) \\
Government ownership concentration (GOC) & Shareholdings held by government \\
Board size (BS) & Total number of directors on the board of directors \\
Board independence (BI) & Proportion of non-executive directors on boards \\
Family directors (FD) & Proportion of family directors on the board \\
\hline & \multicolumn{1}{c}{ Control variables } \\
\hline Firm size (FS) & Natural log of total assets \\
Firm age (FA) & Natural log of listed years on the KSE \\
Industry type (IND) & Oil and gas, basic materials, industrial, consumer goods, health care, consumer \\
$(9$ sectors) & services, telecommunication, real estate, technology \\
\hline
\end{tabular}

\section{Results and Discussion}

Table 3 presents the correlation coefficients matrix for the study variables. This study tested five assumptions of the OLS regression: multicollinearity, autocorrelation, homoscedasticity, linearity, and normality. The results did not indicate any of these problems. No multicollinearity problem emerged as all relationships among variables were less than 80\% (see Table 3), which is consistent with Brooks (2008). Other assumptions were also tested, and the data were linear and normal. Consistent with the studies of Haniffa and Cooke (2002) and Haniffa and Hudaib (2006), the analysis of skewness and kurtosis tests, residual Q-Q plot test and the studentised residuals against predicted values were conducted and indicated no problems of autocorrelation, homoscedasticity, linearity, and normality.

The mean value of the DTE ratio equaled 1.6, with a maximum value of 0.75 and a minimum value of 0.03 (see Table 4). Hussainey and Ajifri (2012) found that the mean value of capital structure in UAE equaled 36\%. Thus, Kuwaiti-listed firms used more debt. The average total large shareholders' ownership concentration was 56\%, compared to 4\% for government ownership concentration. Al-Faraih, Alanezi, and Al-Mujamed (2012) found that institution ownership equaled $45 \%$ while government ownership equaled 3\% in 2010. 
Table 3. Pearson correlation coefficients matrix for the study variables

\begin{tabular}{lllllllll}
\hline & CS & OC & GOC & BS & BI & FD & FS & FA \\
\hline CS & 1 & & & & & & & \\
OC & 0.08 & 1 & & & & & & \\
GOC & -0.05 & 0.092 & 1 & & & & & \\
BS & -0.007 & -0.03 & $0.28 * *$ & 1 & & & \\
BI & -0.051 & 0.036 & -0.047 & 0.010 & 1 & & \\
FD & 0.062 & 0.071 & -0.055 & 0.048 & 0.039 & 1 & $0.15^{* *}$ & 1 \\
FS & 0.08 & 0.041 & 0.090 & $0.38^{* *}$ & 0.065 & & \\
FA & -0.004 & -0.032 & $0.143^{*}$ & $0.27 * *$ & -0.016 & 0.019 & $0.30^{* *}$ & 1 \\
\hline
\end{tabular}

Note. ***,**, Significant at the 0.01. 0.05, and 0.10 levels, respectively (two-tailed). The definition of the variables in table 2 .

Al-Saidi (2013) found that ownership concentration equaled $56 \%$ while government ownership equaled $3 \%$ from 2009 to 2012. Hussainey and Ajifri (2012) found that government ownership in UAE equaled $11 \%$. The average number of total board directors in the listed firms was about 6 persons. Al-Faraih et al. (2012) found that board size equaled 5.8, and Hussainey and Ajifri (2012) found that board size in UAE equaled 7. The mean ratio of non-executive directors to total directors was $85 \%$ and to family directors was $22 \%$.

Table 4. Descriptive statistics for all study variables

\begin{tabular}{lccccc}
\hline Variables & Sample & Minimum & Maximum & Mean & SD \\
\hline CS & 81 & 0.03 & 0.75 & 0.1 & 0.6 \\
OC & 81 & 0 & 0.96 & 0.56 & 0.043 \\
GOC & 81 & 4 & 11 & 6.1 & 0.11 \\
BS & 81 & 0.20 & 1 & 0.85 & 0.22 \\
BI & 81 & 0 & 2.85 & 0.16 \\
FD & 81 & -2.86 & 2.01 & 0.22 \\
FS $(\log )$ & 81 & -2.81 & & 0.99 \\
FA $(\log )$ & 81 & & 0.00 & 0.98 \\
\hline
\end{tabular}

Note. The definition of the variables in table 2.

Table 5 presents the OLS regression results. The adjusted $\mathrm{R}^{2}$ value was $38 \%$, indicating that independent and control variables can explain 38\% of the variation in capital structure (Brooks, 2008). The remaining percentage $(62 \%)$ is affected by other variables not included in this study. Table 5 also shows that the F-value was 13.38 and is significant at the $1 \%$ level. Thus, the two corporate governance mechanisms (i.e., government ownership concentration and family directors) significantly influence the capital structure decisions of the listed companies in Kuwait whereas large shareholders' ownership concentration, board size, and independent directors do not.

Table 5. Ordinary Least Square (OLS) results

\begin{tabular}{|c|c|c|c|}
\hline Variables & Expected relationship & T-value & Hypothesis result \\
\hline $\mathrm{OC}$ & Negative & -1.426 & Rejected \\
\hline GOC & Negative & $-2.639 * * *$ & Accepted \\
\hline BS & Negative & 0.207 & Rejected \\
\hline BI & Positive & -0.187 & Rejected \\
\hline FD & Positive & $1.753^{*}$ & Accepted \\
\hline FS & & $10.163 * * *$ & \\
\hline FA & & 0.635 & \\
\hline IND1 & & -0.378 & \\
\hline IND2 & & -1.576 & \\
\hline IND3 & & 0.020 & \\
\hline IND4 & & -0.434 & \\
\hline IND5 & & $1.828 *$ & \\
\hline IND6 & & -0.030 & \\
\hline IND7 & & -0.387 & \\
\hline IND8 & & -0.205 & \\
\hline $\mathbf{R}^{2}$ & 0.41 & $\operatorname{Adj}-R^{2}=0.38$ & F-Value $=13.38(0.00)$ \\
\hline
\end{tabular}


This study found no significant impact of large shareholders' ownership concentration on capital structure; thus, H1 was not supported, which is inconsistent with agency theory. Agency theory assumes that large shareholders create agency problems within firms. However, the finding is consistent with the findings of Agyei and Owusu (2014), Hafez (2017) in Egypt, and Hakim and Affes (2015) in Tunisia. Finally, Hussainey and Ajifri (2012) studied the situation in UAE as one of the GCC (Note 3) countries and found that large shareholders' ownership concentration negatively affects capital structure.

Furthermore, government ownership concentration negatively affects capital structure, thereby supporting H2. This finding is consistent with agency theory, which argued that large shareholders create conflict inside and outside firms, leading to decreased firm performance and value as well as "tunneling" problems (Johnson et al., 2000) (Note 4). The most likely reason is that increasing firm value is not a priority of the Kuwaiti government, so the government uses its listed firms as a solution for unemployment problems. Therefore, increasing debt would increase the level of bankruptcy, causing many people to lose their jobs. For this reason, the Kuwaiti government wants to keep its firms less risky. Empirically, Quang and Xin (2015) found the opposite to be true in China, while Hafez (2017) found no impact of government ownership concentration on capital structure in Egyptian listed firms. Hussainey and Ajifri (2012) found no significant relationship between capital structure and government ownership.

The results indicated that board size does not impact capital structure, thereby rejecting H3. This is inconsistent with agency theory, which argues that small board size is better (Yermack, 1996). Hussainey and Aljifri (2012) found a similar relationship in UAE, but Chitiavi et al. (2013), Ahmad et al. (2018), Masnoon and Rauf (2013), and Agyei and Owusu (2014) argued that large board size can improve firms' functions more effectively and increase the level of monitoring for managers because more directors means more skill and experience. Meanwhile, Heng and Azrbaijani (2012), Abobakr and Elgiziry (2016), Brenni (2014), Uwuigbe (2014), and Hasan (2009) found that board size negatively affects capital structure.

Inconsistent with agency theory, the study found no relationship between the proportion of board independence and capital structure of a firm; thus, $\mathrm{H} 4$ was not supported. This is probably because non-executive directors in Kuwait are not truly independent and are highly influenced by large shareholders. This finding is consistent with the findings of Quang and Xin (2015), Jaradat (2015), Agyei and Owusu (2014), and Hasan (2009). Kajananthan (2012) found that independent boards in Sri Lanka do not impact capital structure because more debt is riskier.

Family board members positively affect capital structure, supporting H5. This is consistent with agency theory (Jensen \& Meckling, 1976). In countries like Kuwait, a strong relationship exists between families' listed firms and local banks, which is similar to the situation in developing countries and in cases where the board of directors and banks' boards are the same families. In term of control variables, only firm size was found to affect capital structure positively, which means that large firms have more debt. This is consistent with the study of Hussainey and Aljifri (2012), who found that large firms used more debt because they are less likely to go bankrupt because they have more resources and more skilled managers. Thus, Kuwaiti banks are more willing to give large firms more money because they have lower risk. Finally, the study found that firm age does not impact capital structure whereas industry variables impact capital structure in different ways, as suggested by Jensen (1986).

\section{Conclusion}

This study empirically examined the relationship among five corporate governance mechanisms related to the capital structure of 81 non-financial listed firms on the KSE between 2017 and 2018. Only government ownership concentration and family directors were found to be significantly related to capital structure, while large shareholders' ownership concentration, board size, and board independence showed no significant impact. Hussainey and Aljifri (2012, p. 156) explained why agency theory does not work in some countries, meaning some governance mechanisms are not significant on capital structure "because of the different legal, institutional, and culture factors that shape the influence of corporate governance mechanisms on capital structure decision."

This study is the first of its kind to examine the relationship between corporate governance mechanisms and capital structure, and regulators and academic researchers should consider its results. However, this study has some limitations - namely, the time period of study is only two years (2017 and 2018) and the results of this study is relevant to the Kuwait environment. Future studies should consider data from more years, more variables, or additional GCC countries for comparison purposes.

\section{References}

Abobakr, M., \& Elgiziry, H. (2016). The effect of board characteristics and ownership structure on the corporate financial leverage. Accounting and Finance Research, 5(1), 1-14. https://doi.org/10.5430/afr.v5n1p1 
Agyei, A., \& Owusu, A. (2014). The effects of ownership structure and corporate governance on capital structure of Ghanaian listed manufacturing companies. International Journal of Academic Research in Accounting, Finance, and Management Sciences, 4(1), 109-118. https://doi.org/10.6007/IJARAFMS/v4-i1/547

Ahmad, H., Akhter, N., Siddiq, T., \& Iqbal, Z. (2018). Ownership structure, corporate governance and capital structure of non-financial firms of Pakistan. Information Management and Business Review, 10(1), 31-46. https://doi.org/10.22610/imbr.v10i1.2146

Al-Faraih, M., Alanezi, F., \& Al-Mujamed, H. (2012). The influence of institutional and government ownership on firm performance: Evidence from Kuwait. International Business Research, 5(10), 192-200. https://doi.org/10.5539/ibr.v5n10p192

Al-Saidi, M. (2013). Ownership concentration and firm performance: The case of Kuwait. Jordan Journal of Business Administration, 9(4), 803-819. https://doi.org/10.12816/0002094

Boateng, A., Cai, H., Borgia, D., \& Ngwu, F. (2017). The influence of internal corporate governance mechanisms on capital structure decisions of Chinese listed firms. Review of Accounting and Finance, 16(4), 444-461. https://doi.org/10.1108/RAF-12-2015-0193

Boroujeni, H., Noroozi, M., Nadem, M., \& Chadegani, A. (2013). The effects of ownership structure and corporate governance on capital structure. Australian Journal of Basic and Applied Sciences, 7(4), 424-430.

Brenni, P. (2014). Corporate governance and capital structure decisions of UK listed real estate companies. Research Journal of Finance and Accounting, 5(1), 42-54.

Brooks, C. (2008). Introductory econometrics for finance. Cambridge: Cambridge University Press. https://doi.org/10.1017/CBO9780511841644

Butt S. A., \& Hasan, A. (2009). Impact of ownership structure and corporate governance on capital structure of Pakistani listed companies. International Journal of Business and Management, 4(2), 50-57. https://doi.org/10.5539/ijbm.v4n2p50

Cambridge Cadbury Committee. (1992). Report of the committee on the financial aspects of corporate governance. London, UK: Gee Publishing Ltd.

Chitiavi, M., Musiega, M., \& Alala, O. (2013). Capital structure and corporate governance practices. Evidence from listed non-financial firms on Nairobi Securities Exchange Kenya. IOSR Journal of Business and Management, 10(2), 8-16. https://doi.org/10.9790/487X-1020816

Hafez, H. (2017). Corporate governance practices and firms' capital structure decisions: An empirical evidence of emerging economy. Accounting and Finance Research, 6(4), 115-129. https://doi.org/10.5430/afr.v6n4p115

Hakim, N., \& Affes, H. (2015). Effects of internal governance mechanisms on the debt ratio of Tunisian companies. International Journal of Research in Management \& Business Studies, 2(2), 1-6.

Haniffa, R., \& Cooke, T. (2002). Culture, corporate governance, and disclosure in Malaysian corporations. ABACUS, 38(3), 317-349. https://doi.org/10.1111/1467-6281.00112

Haniffa, R., \& Hudaib, M. (2006). Governance structure and firm performance of Malaysian companies. Journal of Business Finance and Accounting, 33, 1034-1062. https://doi.org/10.1111/j.1468-5957.2006.00594.x

Heng, T., \& Azrbaijani, S. (2012). Board of directors and capital structure: Evidence from leading Malaysian companies. Asian Social Sciences, 8(3), 123-136. https://doi.org/10.5539/ass.v8n3p123

Hussainey, K., \& Aljifri, K. (2012). Corporate governance mechanisms and capital structure in UAE. Journal of Applied Accounting Research, 13(2), 145-160. https://doi.org/10.1108/09675421211254849

Jaradat, M. (2015). Corporate governance practices and capital structure: A study with special reference to board size, board gender, outside director and CEO duality. International Journal of Economics, Commence and Management, 3(5), 264-273.

Jensen, M. C. (1986). Agency cost of free cash flow, corporate finance and takeovers. American Economic Review, 76, 323-329.

Jensen, M. C., \& Meckling, W. H. (1976). Theory of the firm: Managerial behavior, agency cost and ownership structure. Journal of Financial Economics, 3, 305-360. https://doi.org/10.1016/0304-405X(76)90026-X

Johnson, S., La Porta, L., Lopez-de-Silanez, F., \& Shleifer, A.(2000). Tunneling. American Economic Review, 90(2), 22-27. https://doi.org/10.1257/aer.90.2.22 
Kajananthan, R. (2012). Effect of corporate governance on capital structure: Case of the Sri-Lankan listed manufacturing companies. Journal of Arts, Sciences \& Commerce, 4(1), 63-71.

La Porta, R., Lopez-de-Silanes, F., \& Shleifer, A. (1999). Corporate ownership around the world. Journal of Finance, 54, 471-517. https://doi.org/10.1111/0022-1082.00115

Masnoon, M., \& Rauf, M. (2013). Impact of corporate governance on capital structure - A study of KSE listed Firms. Global Management Journal for Academic \& Corporate Studies, 3(1), 94-110.

Modigliani, F., \& Miller, M. (1958). The cost of capital, corporation finance and the theory of investment. American Economic Review, 48(3), 261-297.

Quang, D., \& Xin, W. (2015). Measuring impact of ownership structure and corporate governance on capital structure of Vietnamese SOES. European Journal of Business and Social Sciences, 4(8), 218-230.

Siromi, B., \& Cbandrapala, P. (2017). The effects of corporate governance on firms' capital structure of listed companies in Sri Lanka. Journal of Competitiveness, 9(2), 19-33. https://doi.org/10.7441/joc.2017.02.02

Uwuigbe, U. (2014). Corporate governance and capital structure: Evidence from listed firms in Nigeria stock exchange. Journal of Accounting and Management, 4(1), 5-14.

Yermack, D. (1996). Higher market valuation of companies with a small board of directors. Journal of Financial Economics, 40, 185-221. https://doi.org/10.1016/0304-405X(95)00844-5

\section{Notes}

Note 1. According to the new corporate governance rules, all listed firms must separate the roles of the chairman and the CEO. Thus, this variable is no longer available in Kuwait

Note 2. Kuwait's government introduced a new code for corporate governance and new companies law that provided more details about disclosure, shareholders' role, and board composition in June 2016. Thus, before 2017, no corporate governance rules were used in the Kuwait Stock Exchange (KSE).

Note 3. GCC countries include six countries: Kuwait, Bahrain, Oman, UAE, Saudi Arabia, and Qatar.

Note 4. Johnson et al. (2000) argued that tunneling refers to the action by large shareholders to transfer benefits of listed firms and support tender guarantees for shareholders' loans with a favorable price.

\section{Copyrights}

Copyright for this article is retained by the author(s), with first publication rights granted to the journal.

This is an open-access article distributed under the terms and conditions of the Creative Commons Attribution license (http://creativecommons.org/licenses/by/4.0/). 